\title{
Forceful Contact in a Result Prominent Language
}

\author{
Ronald P. Schaefer*
}

LSA Annual Meeting, Portland, January 8-11, 2015

1.0 Introduction. Levin and Rappaport Hovav (1995) remind us that manner and result verbs exhibit complementary distribution within a given language. When a main verb lexicalizes manner or result, the complementary component is expressed in a satellite constituent of some sort. Building on this, Erteschik-Shir and Rapoport (2010) examine English verbs of surface contact, e.g. smear, splash, whose complements specify a result relation between a moveable object and stationary locatum. Levin (2012) scrutinizes crosslinguistic variation in one type of surface contact event, i.e. HITTING, where, a verb characterizes surface contact with a physical object through forceful impact without entailing change in physical object state. A HITTING verb expresses a relation between a force recipient/surface and an instrument/moving object.

For this paper I examine forceful contact expressions in Emai, West Benue Congo and Edoid (Williamson and Blench 2000). Relatively strict SVO, Emai manifests little inflectional morphology and few prepositions while expressing simple and complex predications. The latter employ verbs in series or a verb plus postverbal particle.

In its motion domain, Emai predications express manner and result through distinct verbs. A manner verb, (la 'run'), occurs in series with a result verb, (shan 'move through').

$$
\begin{aligned}
& \text { òjè lá shán ékéín ìwè. } \\
& \text { Oje PRP.run move.through inside house } \\
& \text { 'Oje ran through the house.' }
\end{aligned}
$$

For predications expressing contact, Emai relies on a wider range of resources. It shows surface contact and point of contact as well as contact with forceful impact.

2. Surface Contact. For surface contact without forceful impact, Emai employs a manner verb (e.g. sion 'thread') in construction with postverbal particle $\underline{o}$ 'onto' expressing result as a change of locational state (CL). Instrument or moving object occurs as manner verb direct object and surface as the particle's locative (LOC) marked oblique object.

àlèkè síón ìvié ó vbí uiì.

Aleke PRP.thread corral-beads CL LOC string

'Aleke threaded corral beads onto a string.'

3. Point of Contact. For point of contact without forceful impact, Emai relies on verbs in series: an initial transitive manner verb followed by a result component, either full verb or verb leached of much erstwhile semantic content. Instrument is expressed as manner verb direct object and surface point of contact is articulated as locative oblique object of the second verb in series.

$$
\begin{aligned}
& \text { a. òjè nwú ón òn gón vbí ùdékèn. } \\
& \text { Oje PRP.take-hold pole be.off.center LOC wall } \\
& \text { 'Oje leaned the pole against the wall.' }
\end{aligned}
$$

\footnotetext{
* Data derive from research sponsored by NSF (BNS \#9011338 and SBR \#9409552), NEH (PD-50004 -06) and DOS through CUAP (ASJY 1333). Data interpretation rests with me alone. Abbreviations are $C L=$ change of location, LOC=locative and PRP=present perfect. Author: Southern Illinois University Edwardsville.
} 
b. òjè nwú ólì èkpà khúán vbí ólí óràn.

Oje PRP.take.hold the bag suspend LOC the tree

'Oje hung the bag in the tree.'

Non-forceful contact events thus exhibit two noteworthy characteristics. The contact result achieves grammatical prominence through a postverbal particle or verb in series. And the argument expressing surface where contact occurred appears as locative marked oblique object.

4. Contact with Forceful Impact. For contact with forceful impact, i.e. HITTING events, there are two framing patterns. Each lacks a verb in series or a postverbal particle; instead, they have in common a double object construction when the surface argument is animate.

HITTING type one is illustrated by verb fi 'hit.' Its complement type depends on animacy of surface argument: inanimates as complex transitive constructions with oblique object and animates as double object constructions with optional oblique object. When inanimate, surface occurs in a locative ( $v b i)$ marked oblique object, while instrument appears as transitive direct object or intransitive subject.
a. òjè fí úkpórán vbì òtọì.
Oje PRP.hit stick LOC ground
'Oje hit a stick on the ground.'
b. úkpóràn fí vbì òtò̀.
stick PRP.hit LOC ground
'A stick hit on the ground.'

When animate, surface is first object and instrument second. Surface serves as external possessor for a locative-marked oblique object limited to a body part, which is syntactically optional.

(5) a. òjè fí òlóló úkpórán vbì ùòkhò.

Oje PRP.hit Ololo stick LOC back

'Oje hit Ololo with a stick on the back.'

b. òjè fí òlóló úkpóràn.

Oje PRP.hit Ololo stick

'Oje hit Ololo with a stick.'

When surface is animate, and instrument occurs as subject, surface retains external possessor role relative to a locative marked oblique object body part. Unlike in double object constructions, the locative marked body part is not syntactically optional. In addition, neither body part nor external possessor alone can occur as direct object.
a. úkpóràn fí òlóló vbì ùòkhò.
stick PRP.hit Ololo LOC back
'A stick hit Ololo on the back.'
b. *úkpóràn fí òlólò / ùòkhò.
stick PRP.hit Ololo back
'A stick hit Ololo / his back.'

Moreover, as a simple transitive verb, $f i$ 'hit' fails to occur with human nouns as implicit instrument subject and surface direct object. 
HITTING type two expresses contact with forceful impact via complex nominal relations in either a complex transitive or double object construction. It articulates differentially depending on whether surface is inanimate or animate. When inanimate, surface appears as locative marked oblique object. When animate, surface shows up as external possessor in first object position relative to a syntactically optional locative oblique object as body part possessum. Meanwhile, relative to grammatical subject as external possessor, instrument occurs as body part possessum in direct object position when surface argument is inanimate or in second object position when surface argument is animate.

HITTING events of type two are lexically related to syntactically simple predications of forceful contact. Transitive so 'collide with, bang into' or hian 'strike' express forceful impact between two entities, direct object conveying surface or instrument, respectively.
a. òjè só ùdékè̀n.
Oje PRP.collide wall
'Oje collided with / banged into the wall'
b. òjè híán ìsánó.
Oje PRP.strike match
'Oje struck a match.'

Lexically related complex predications code instrument and surface with one or more external possessor constructions, depending on surface argument animacy. Type two events with verb so take èkpà 'fist,' ízà 'heel' and úkpà 'beak,' while those with verb hian take àkòn 'tooth' and éhiên 'fingernail.' With inanimate surface, body-part possessum instrument occurs as direct object, its possessor as subject and inanimate surface as locative marked oblique object.

$$
\text { òjè só ékpá vbì ìtébù. }
$$

Oje PRP.collide fist LOC table

'Oje's fist collided with the table / Oje punched the table.'

With animate surface, body part possessum instrument is retained but as second object. As first object and as surface, we find an external possessor relative to a distinct body part possessum as locative marked oblique object. Oblique object is optional.

$$
\begin{aligned}
& \text { a. òjè só òlóló ékpá vbì è̀ò. } \\
& \text { Oje PRP.collide Ololo fist LOC face } \\
& \text { 'Oje’s fist collided with Ololo's face / Oje punched Ololo in the face.' } \\
& \text { b. òjè só ònló èkpà. } \\
& \text { Oje PRP.collide Ololo fist } \\
& \text { 'Oje’s fist collided with Ololo / Oje punched Ololo.' }
\end{aligned}
$$

There is however no complex transitive predication with surface split between direct and oblique object positions. Nor does simple transitive combine possessors without their body parts, subject possessor and animate surface, or subject possessor with body part. 
(11)
a. *òjè só òlóló vbì èò.
Oje PRP.collide Ololo LOC face
'Oje punched Ololo in the face.'
b. *òjè só òlólò / èkpà.
Oje PRP.collide Ololo fist
'Oje punched Ololo / banged his fist.'

Other contact with forceful impact expressions with verb so include:
a. ólí óókhò só úkpá vbí íjén'n.
the chicken PRP.collide beak LOC charcoal
'The chicken pecked the charcoal / The chicken's beak collided with the charcoal'
b. ólí óókhò só òlóló úkpá vbì àwè̀.
the chicken PRP.collide Ololo beak LOC leg
'The chicken pecked Ololo's legs / The chicken's beak collided with Ololo's legs.'

Forceful impact with body-part instrument expressions with verb hian include:
a. òjè híán òlóló ákón vbí òè.
Oje PRP.strike Ololo tooth LOC leg
'Oje bit Ololo’s leg / Oje’s teech struck Ololo’s leg.'
a. òjè híán òlóló éhiên vbí òè.
Oje PRP.strike Ololo fingernails LOC leg
'Oje pinched Ololo's leg / Oje’s fingernail struck Ololo's leg.'

5. Conclusion: Contact with forceful impact, unlike other Emai contact expressions, does not rely on multiple predicative elements. Instead, it codes its animate arguments in a split fashion, differentially coding a surface of contact argument according to animacy. Inanimate surface appears as oblique object, while animate surface entities are split, possessor occurring as first object and possessum as oblique object. Instruments are differentially coded syntactically according to animacy, showing two HITTING event types. Inanimate instrument appears as direct object in complex transitive constructions or second object in double object constructions (HITTING type one), while animate instruments are split, possessor appearing as subject and possessum as direct object in complex transitive constructions or second object in double object constructions (HITTING type two). Animacy thus gives rise to external possessor constructions affecting the syntactic positioning of surface and instrument arguments in Emai contact with forceful impact events.

\section{References}

Erteschik-Shir Nomi \& Tova Rapaport. 2010. Contact and other results. In Lexical Semantics, Syntax and Event Structure, Malka Rappaport Hovav, Edit Doron \& Ivy Sichel (eds.). New York: Oxford University Press.

Levin, Beth. 2012. Slap, give a slap, slap a slap: crosslinguistic diversity in hitting event descriptions. HDLS 10. Levin, Beth \& Malka Rappaport Hovav. 1995. Unaccusativity: At the Syntax-Lexical Semantics Interface. Cambridge, MA: The MIT Press.

Schaefer, Ronald P. \& Francis O. Egbokhare. 2007. A Dictionary of Emai: An Edoid Language of Nigeria. Cologne: Rüdiger Köppe Verlag.

Williamson, Kay \& Roger Blench. 2000. Niger Congo. In African Languages: An Introduction, Bernd Heine \& Derek Nurse (eds.), 11-42. New York: Cambridge University Press. 